\title{
A traitor's death? The identity of a drawn, hanged and quartered man from Hulton Abbey, Staffordshire
}

Article

Published Version

Lewis, M. E. (2008) A traitor's death? The identity of a drawn, hanged and quartered man from Hulton Abbey, Staffordshire. Antiquity, 82 (315). pp. 113-124. ISSN 0003-598X Available at https://centaur.reading.ac.uk/3748/

It is advisable to refer to the publisher's version if you intend to cite from the work. See Guidance on citing.

Published version at: http://antiquity.ac.uk/ant/082/ant0820113.htm

Publisher: Antiquity Publications

All outputs in CentAUR are protected by Intellectual Property Rights law, including copyright law. Copyright and IPR is retained by the creators or other copyright holders. Terms and conditions for use of this material are defined in the End User Agreement.

www.reading.ac.uk/centaur

\section{CentAUR}

Central Archive at the University of Reading 
Reading's research outputs online 


\section{A traitor's death? The identity of a drawn, hanged and quartered man from Hulton Abbey, Staffordshire}

Mary E. Lewis*

Analysis of a set of bones redeposited in a medieval abbey graveyard showed that the individual had been beheaded and chopped up, and this in turn suggested one of England's more gruesome execution practices. Since quartering was generally reserved for the infamous, the author attempts to track down the victim and proposes him to be Hugh Despenser, the lover of King Edward II.

Keywords: Hulton Abbey, execution, quartering, perimortem trauma, Hugh Despenser the Younger, Edward II

\section{Introduction}

The disarticulated skeletal remains (HA16) of a mature adult male, around 5 feet 8 inches in height $(178 \mathrm{~cm})$, were uncovered during the 1970 s excavation of the Cistercian monastery of Hulton Abbey, Staffordshire (Figure 1a). The bones of this individual are remarkable because they display numerous perimortem cut marks throughout. Browne (2004) has suggested that the cut marks are battle injuries and that additional cut marks were added when the body was 'divided' and boiled to allow for its transportation back to Hulton Abbey for burial. A re-analysis of the remains suggests that in fact, the body had been quartered; a brutal form of execution reserved for the most notorious of criminals. This has led to a new investigation into the possible identity of the remains, and the first osteological description of the lesions associated with this practice.

Hulton Abbey (AD 1219-1538) was a relatively poor estate owned by the Audleys of Heleigh whose family rose to prominence in the courts of Edward I and Edward II. The burial place suggests that the remains belonged to a wealthy member of the congregation, and potentially, to one of the Audley family. However, it seemed that the skeleton had been disturbed from an original coffin burial after the dissolution, and was re-deposited, along with some bones of an adult female, near a post-medieval well in the Chancel area (Wise 1985) (Figure 1b).

\section{Distribution of cut marks}

The pathology of the skeleton is consistent with its having been cut up with a sharp blade. The distribution of the cut-marks on HA16 can be seen in Figure 2. The skeleton comprised

* Department of Archaeology, School of Human and Environmental Studies, University of Reading, Reading, Berkshire RG6 6AB, UK (Email: m.e.lewis@reading.ac.uk) 

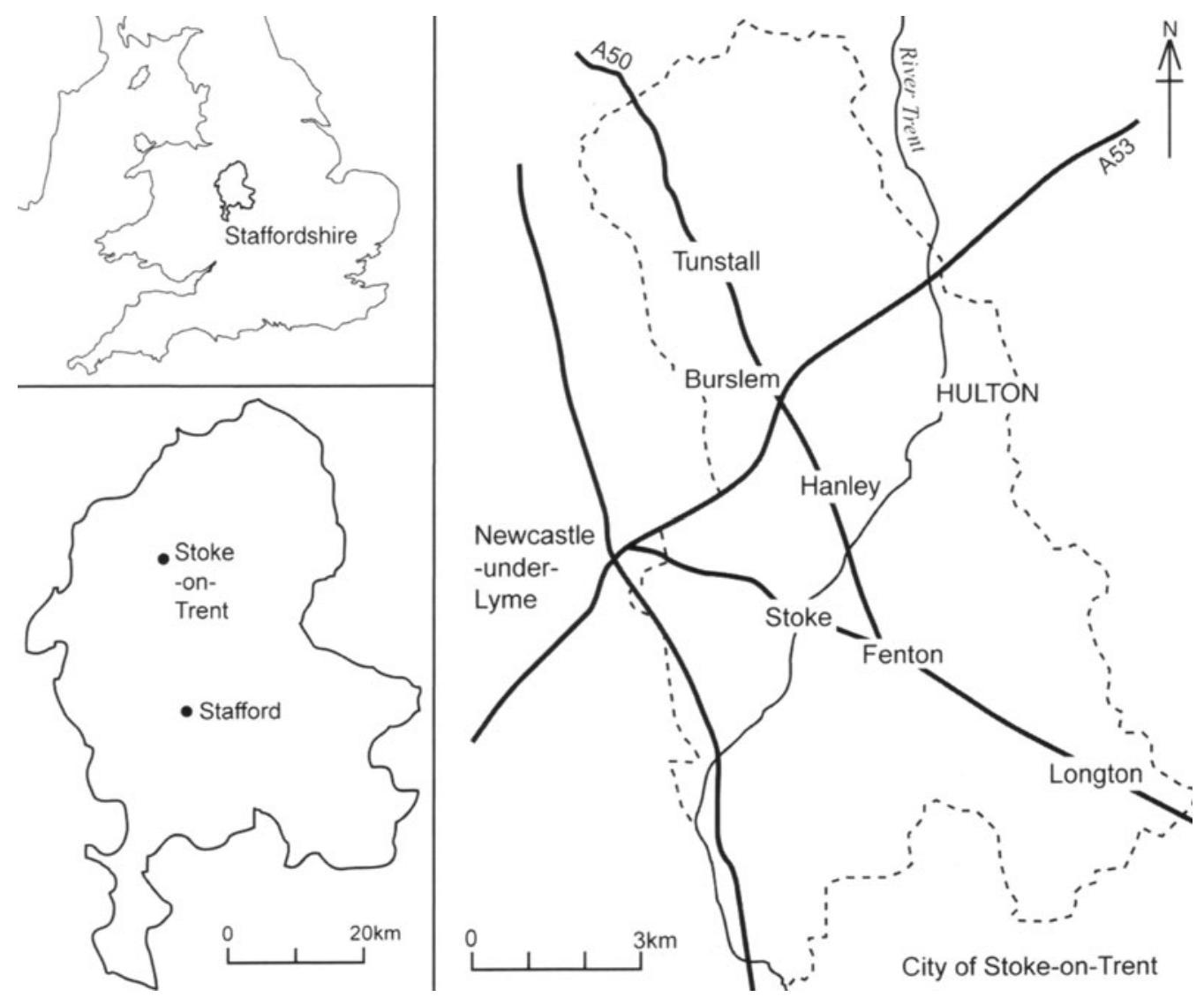

Figure 1a. Location of Hulton Abbey (from Klemperer \& Boothroyd 2004: 3).

an almost complete set of spinal vertebrae, from the third cervical (neck) vertebra to the second lumbar (L2), right and left arms and shoulders, right femur, left and right lower legs. The ribs were poorly preserved and the sternum was not recovered. There were some fragments of the ilium, and one pubic symphysis, suggesting that the pelvis had been included in the burial. No hand or foot bones were linked to this skeleton. Although no skull was present, cut marks on the third cervical vertebra (C3) of the neck indicate the individual was beheaded (Figure 3). Additional cut marks on the right superior facet of C3 indicate that further slices were necessary to completely remove the head. Although badly eroded postmortem, the next vertebrae (C4 to C6) appear normal. A smooth depression on the superior aspect of the seventh cervical vertebra, triangular in shape and measuring $9.8 \mathrm{~mm}$ by $5.9 \mathrm{~mm}$, indicates that the individual was stabbed in the throat (Figure 4). It is not possible to know if this happened before or after the beheading, but the following first thoracic vertebra (T1) is not affected. A further possible stab wound is located in the right inferior margin of $\mathrm{L} 2$ suggesting that the victim had also been stabbed in the stomach (Figures 5 and 6).

Sectioning of the body is indicated by the division of the second and third thoracic vertebrae along the sagittal plane (vertically) which ceases at T4, with no further cut marks 


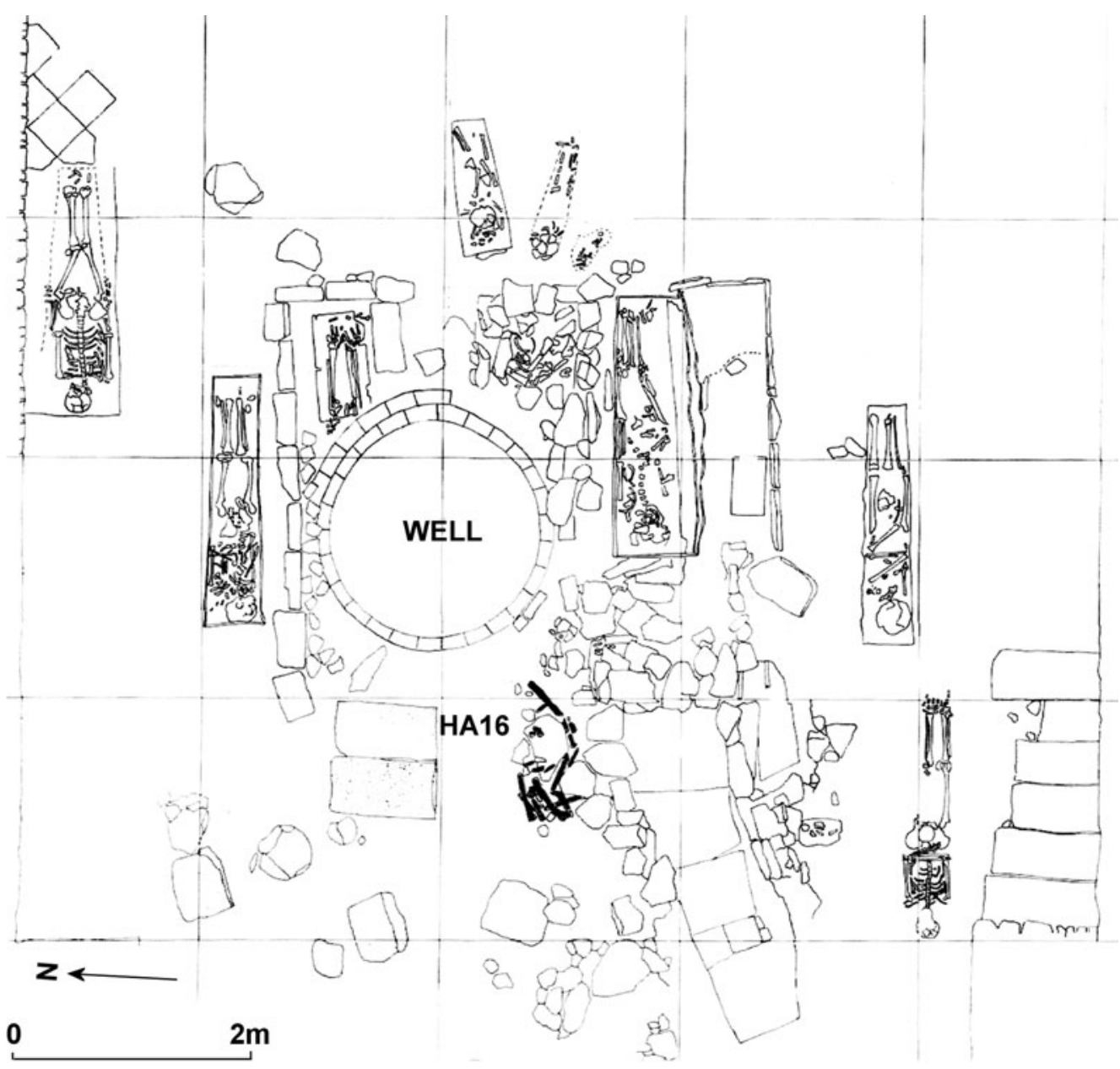

Figure 16. Detail of burials in the chancel of Hulton Abbey showing the location of HA16 (adapted from Wise 1985: 89).

until T11, with T11 to L2 again cleanly cut along the sagittal plane (Figure 7). Notably, the first lumbar vertebra (L1), positioned just above the pelvis in life, also displays a horizontal (transverse) cut, suggesting that after the vertical division, the body was chopped in half (Figure 8) and the entire thorax treated as one section.

Both hands had been removed, with the left radius (lower arm bone) cut further up the wrist than the right. The left radius also displays two small hesitation marks along the shaft, which are in the wrong position to constitute parry or defence wounds, but may suggest an attempt to remove flesh from the bones. The deliberate nature of the division of the body is best demonstrated by the chop marks on the left shoulder. The clavicle (collar bone) bears the marks of an old soft tissue injury that caused ossification of the trapezius muscle and the formation of a new joint (pseudo-arthrosis). This mass of bone would have been unexpected in a normal dissection, and so may account for the numerous chop marks. These cuts have been made from right to left, running from the medial aspect to the lateral aspect of the 


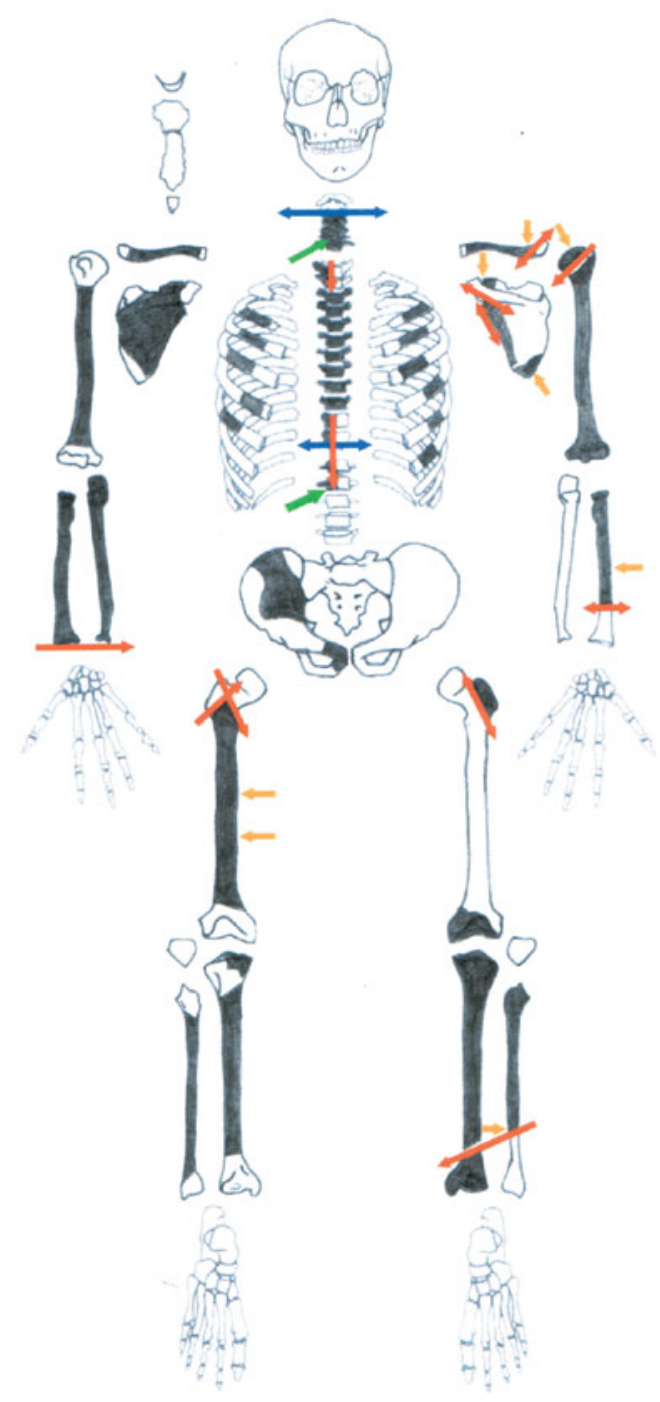

Figure 2. Distribution of perimortem cut marks in HA16. The green arrows indicate stab wounds; red arrows indicate cut marks on the anterior aspect of the skeleton; blue arrows show horizontal cuts and the yellow arrows indicate cut marks to the posterior aspect of the skeleton. shaft. There is an additional sharper cut at the acromial end, made in the opposite direction, and overlies the second chop mark (Figure 9). Other evidence for the deliberate removal of the arm from the shoulder is the removal of the humeral head, cut marks on the shoulder blade (scapula), and a chop mark at the position of the coracoid process at the top of the shoulder. These cuts are consistent with someone attempting to cut around the ligaments that hold the shoulder joint in place (Figure 10).

On the lower body, the right hip has been dissected below the greater trochanter, which was not recovered. This bone however, is the only part of the proximal femur preserved on the left side, suggesting a similar pattern of removal for both legs. Chop marks to the back of the right femur, along the linear aspera, may be the result of trauma from a blade, similar to that seen in battle injuries. On the right lower leg, the fibula appears to have been cut just below the midshaft, with the blade injury following a line through to the tibia.

\section{Interpretation}

Such systematic cutting of bones is suggestive of a ritual exercise in dismemberment, such as quartering, an execution practice prevalent in the English Middle Ages (AD 1100-1500). No cases of suspected quartering have ever been described in the archaeological literature, although Marfart et al. (2004) did report on an instance of postmortem heart ablation from Ganagobie Priory in France. It is possible that the lesions seen on HA16 are the result of medieval funerary practice (mos teutonicus), where nobles who died away from home were dismembered and the pieces boiled in water or wine, with their viscera buried at their place of death (Park 1995). This generally involved the disembowelment, dismembering and boiling of the body, often with requests for the heart to be buried at home (Brown 1981). This 'division of the body' was outlawed by an outraged Boniface VIII in 1299. Heart ablation 


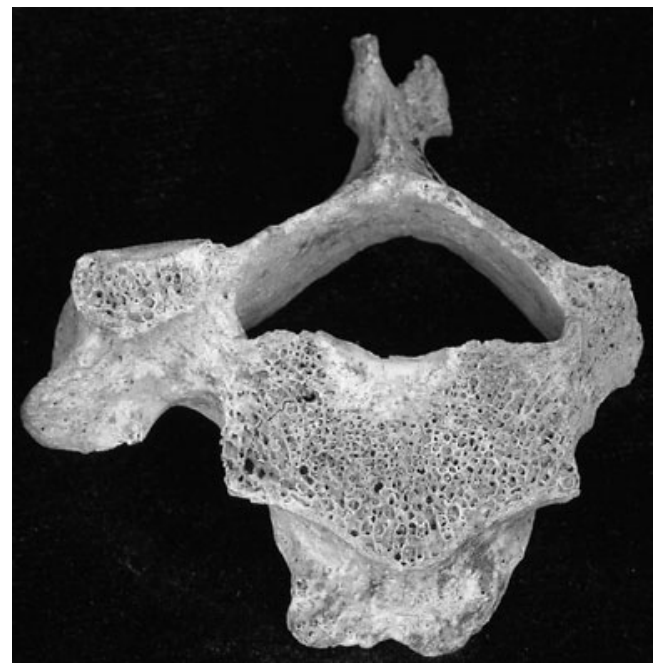

Figure 3. Cut marks on the third cervical vertebra indicative of beheading.

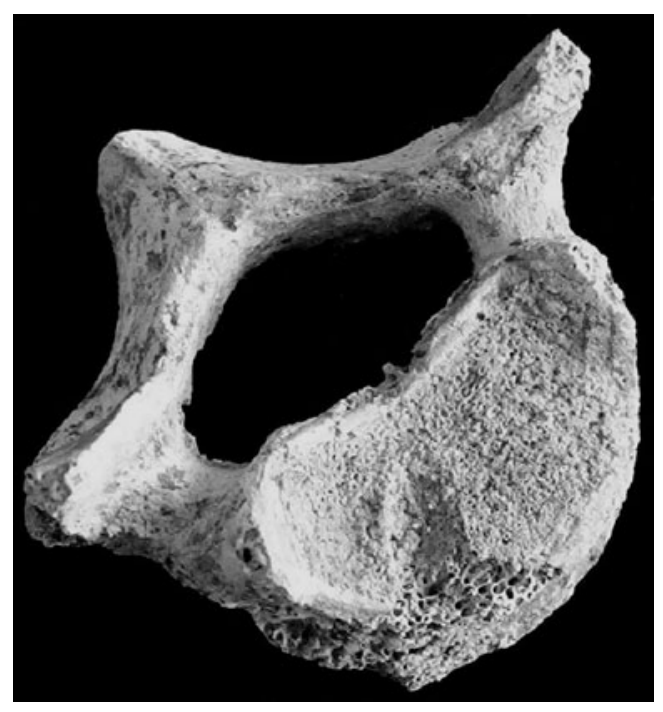

Figure 4. Close-up of stab wound on the seventh cervical vertebra $(C 7)$. (cutting out) may have occurred in the case of HA16, but this involves the sternum, which was not recovered. The ribs are in poor condition, but none of the fragments reveal evidence of cut marks. The normal process of this type of execution involved evisceration; where the intestines were removed and burned in front of the crowd. This would have meant cutting through the soft tissue of the belly, and is unlikely to have left any cuts on the bone itself. The lesions to the vertebral bodies are inconsistent with the incidental and superficial cuts that might result from evisceration, and they have not been reported in the osteological literature before.

\section{Drawing, hanging, and quartering as a form of execution}

Fourteenth-century England was plagued by political tension and turmoil (Phillips 2000) and treason was a crime which deserved the worst torments and cruellest death that could be devised (Finucane 1981). This form of public execution was high theatre which aimed to demonstrate the power of the government to the masses (Cohen 1989). Before 1283, the common punishment for treason was to be dragged to the place of hanging by a horse's tail (hence 'drawn'). The family of the accused would lose their property and in some cases the children would also be executed (Bellamy 1970: 28). In the late thirteenth century, Edward I added disembowelling, burning, beheading and quartering to the ritual, specifically for the execution of Dayfd ap Gruffydd, leader of the Welsh rebellion (Royer 2003). High treason dictated that the perpetrator should suffer more than one death. Hence, each part of ap Gruffydd's execution ritual was designed to make a statement about each of his crimes. Because he betrayed the king, he was drawn at the horse's tail, he was hanged for murder, disembowelled for sacrilege and his entrails burned, and because he had plotted the king's death in several different parts of the realm, his body was to be quartered and limbs 


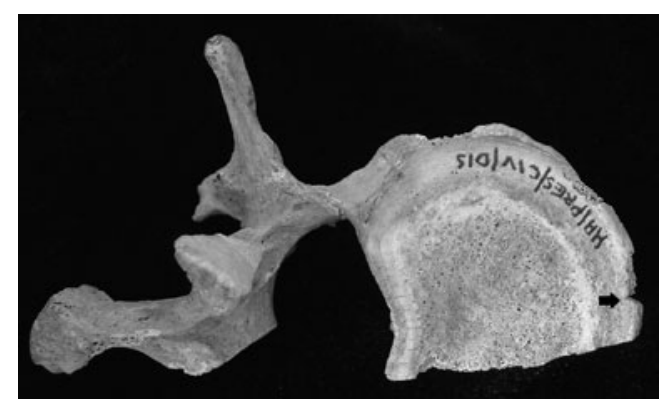

Figure 5. The second lumbar vertebra viewed from the superior aspect, showing a knick on the anterior margin.

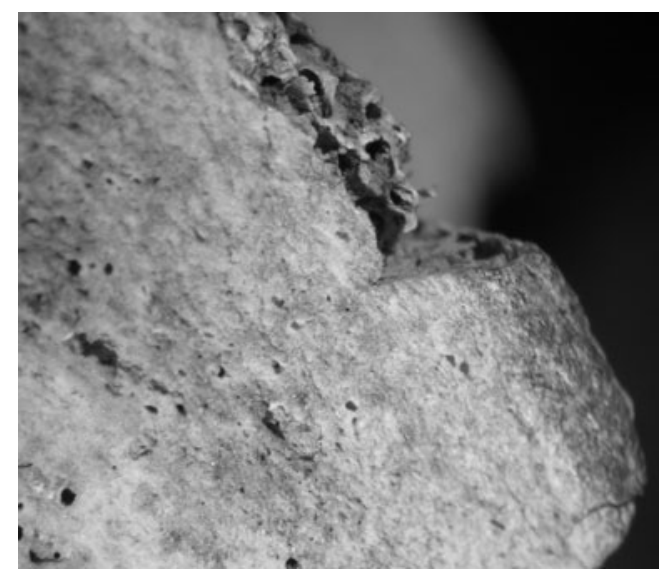

Figure 6. Close-up of knick on the margin of the second lumbar vertebra, possibly indicating a stab wound to the stomach. dispatched to where they could act as a warning to others (Bellamy 1970: 26; Pollock \& Maitland 1968: 501).

By the time Edward I died in 1307, several men had been executed in this fashion. They were usually dragged to the place of execution on a hurdle to ensure that they would be alive when they were hanged, before being disembowelled and finally beheaded (Barron 1981). The head and quarters of the body were parboiled, and sent to locations where the traitor had found support, or where treason had been conspired, and hung on town gates, walls and gibbets, using poles or chains. Relatives would have to wait until they were officially 'thrown down' before they could retrieve the remains for burial (Bellamy 1979: 208). This form of execution reached its height in the 1320s, and by the fifteenth century, it was more usual for nobles to be punished by beheading (Royer 2003).

Depictions of the actual mechanisms behind quartering of the body do not survive, and there was probably no call for them to be written down. What constituted 'quarters' may be inferred from the description of ap Gruffydd's execution,

where his body was cut into four parts and sent to be displayed '. . to wit - the right arm at Bristol; the right leg and hip at Northampton; the left leg at Hereford' (Maxwell 1913: 35). This does not suggest division of the torso, but evidence for that practice may be found in medieval woodcuts, for example, that of the execution of Thomas Armstrong in 1683 (Figure 11).

\section{Identity of the remains}

Radiocarbon analysis carried out by the Oxford Laboratory in 1990 (Hedges et al. 1991) dated the remains to AD 1215-1285 (one sigma, 68 per cent confidence) or AD 1050-1385 (two sigma, 95 per cent confidence). In her report on the Hulton Abbey skeletal remains, Browne (2004) proposed Sir William Audley (AD 1254-1282) as a likely candidate for the burial. William, aged 28, was killed in Anglesey on 6 November 1282 fighting for Edward I during the rising of the Welsh Princes. William and his men crossed the Menai Straits on a bridge of boats, but their return was cut off by the rising tide (Wrottesley 1887). The Welsh attacked and 213 men were slaughtered. Browne went on to suggest that William may have 


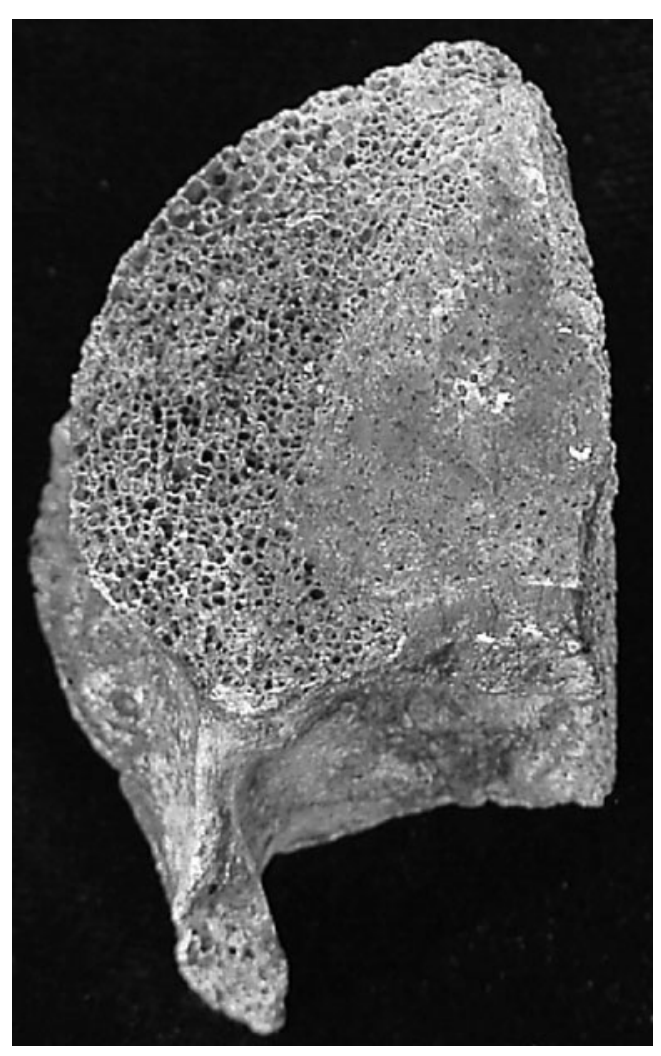

Figure 7. Horizontal cut through the first lumbar vertebra suggesting separation of the thorax from the rest of the body. been captured and mutilated by the Welsh rebels, and his body later retrieved by his brother Nicholas who performed mos teutonicus on the body to allow for its transport to Hulton Abbey.

Osteological analysis of the remains identified the male to have been over 34 years of age (mean 61 years) based on the morphology of the pubic symphyses, and too old to be William. Hence, Tomkinson (1997) has argued that William's cousin, Sir Hugh Audley was a more likely candidate. $\mathrm{He}$ had been one of the nobles who had sided with Thomas, Earl of Lancaster against Edward II in 1322, and had been imprisoned for treason at Wallingford in 1325. He would have been 65 years of age. There is no evidence that Hugh Audley was ever released from prison and it is more likely that he died in Wallingford Castle in 1326 (Cockayne 1919: 348). He was never executed. Dating of the Hulton Abbey skeleton indicates that he died no later than $\mathrm{AD} 1385$, when this very brutal and public form of execution was handed out only to the most notorious political prisoners. This suggests that the skeleton

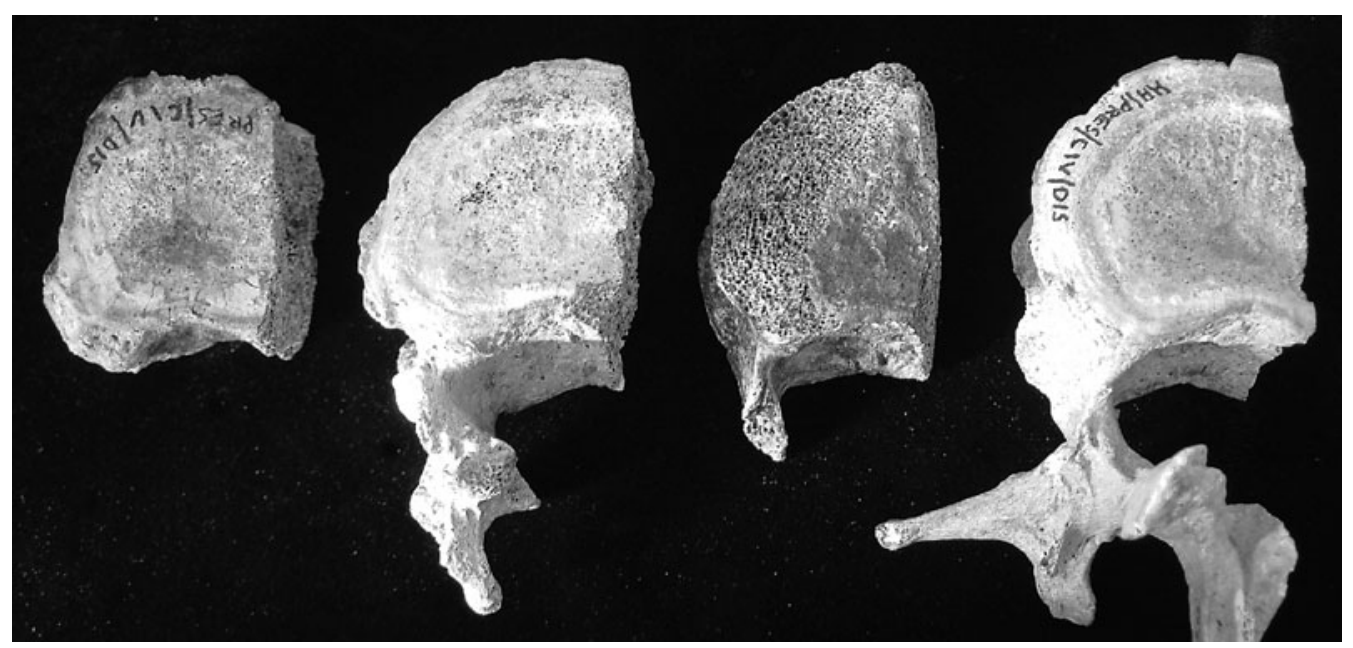

Figure 8. Sagittal cuts through T11 to L2. 


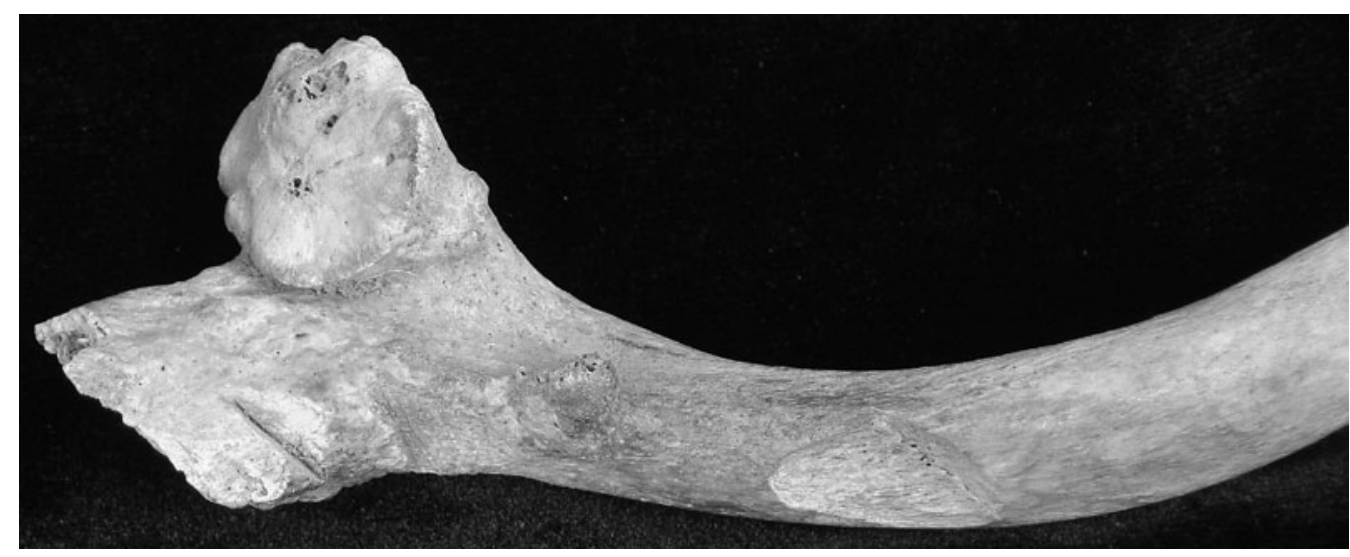

Figure 9. Close-up of cut marks to the left clavicle, and pseudo-arthrosis.

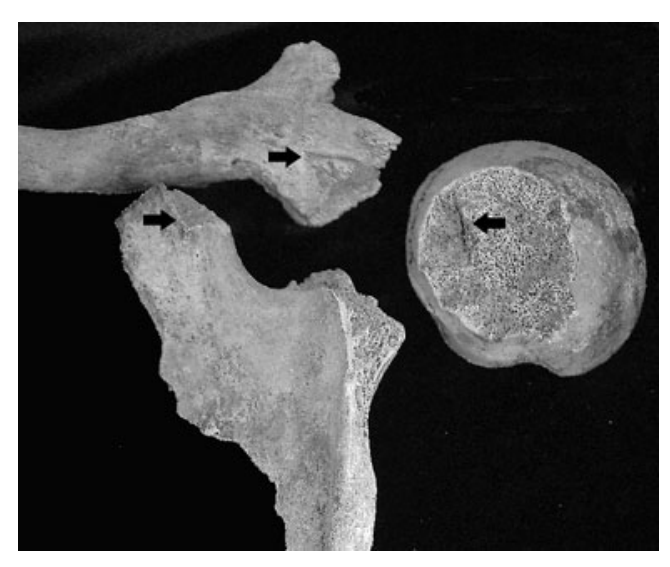

Figure 10. Cut marks to the left shoulder. Note soft tissue ossification on the clavicle and cut marks to the humeral head. at Hulton Abbey was a well known political figure during this period. There is one far more notorious candidate for the identity of the remains at Hulton Abbey: Sir Hugh Despenser the Younger.

Hugh Despenser the Younger was the son of Hugh Despenser, Earl of Winchester, and an advisor to Edward II. Hugh was married to Eleanor de Clare, niece of Edward II who, with her two sisters Margaret and Elizabeth, was heiress to one of the largest fortunes in England. On the death of Eleanor's brother, Gilbert de Clare, Despenser used his political influence to appropriate the lands that should have been divided equally between the sisters (Holmes

1955). In order to succeed in his plan, Despenser attacked his brothers-in-law, Roger Damory, married to Elizabeth, and more importantly, Hugh Audley of Hulton Abbey, who had married Margaret. In 1317, Despenser claimed that Audley was withholding his share of the Welsh estates from him. Not wishing to wage war, Audley exchanged his Welsh estates for poorer lands in England. Despenser next exerted similar pressure on Damory and later, had them both falsely charged and convicted of treason.

Despenser's influence in court came from his being a favourite of Edward II, and it was rumoured that he was the king's lover. When England was invaded in 1326 by Queen Isabella and her consort Roger Mortimer, Despenser was captured and executed at Hereford (Holmes 1955). He was 40 years of age. Edward II abdicated and was killed in 1327 (Valente 1998). The power that Despenser had wielded in the court, and perhaps his personal relationship with the king, had outraged Isabella to such an extent that his execution was 


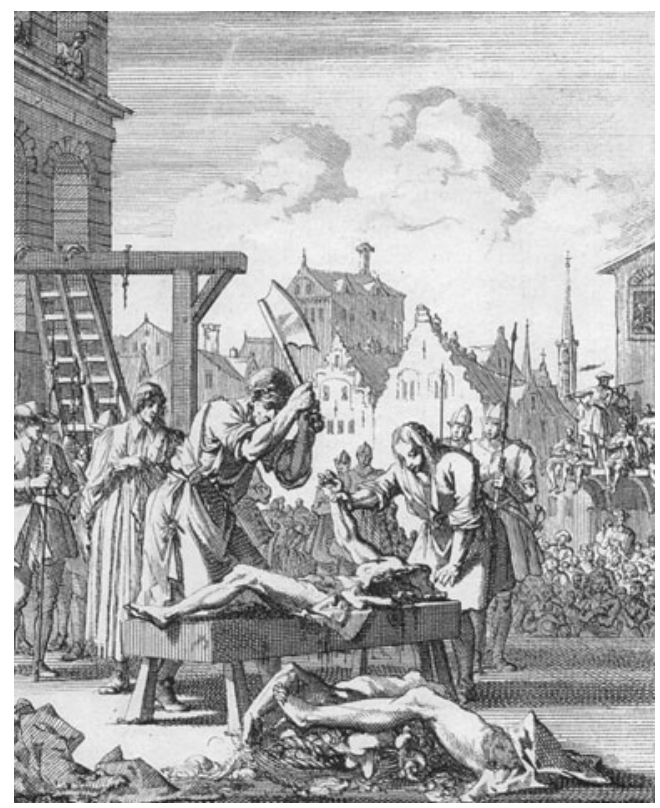

Figure 11. Engraving depicting the execution of Sir Thomas Armstrong in 1683. Note the vertical cuts through the spine and detachment of the legs through the hip. particularly public and brutal. His crimes and their punishments are outlined thus:

$\therefore$ as a thief therefore you shall be hanged; as a traitor. . you shall be drawn and quartered, and your quarters dispersed throughout the kingdom; and as you were outlawed, by our Lord the King and by general consent, and have come back to the court. . you shall be beheaded; and because at all times you have been disloyal and a formenter of strife between our Lord the King and our most noble Lady the Queen. . you shall be disembowelled, and after that you bowels shall be burned. Confess yourself a traitor and a renegade! And so go to meet your doom. Traitor! Evildoer!! and Convicted!!!' (Brigstocke Sheppard 1889: 413)

Hence, on the 16th November 1326, Despenser was publicly humiliated by being stripped and dressed in reversed arms, with a crown of nettles placed on his head (Fryde 1979: 192). He was then roped to four horses, rather than the usual two, and dragged through Hereford, where he was hanged, or rather choked, on gallows at 50 feet with his body supported by a ladder. Medieval chronicler Jean Froissart (c.1337-1405) reported that Hugh was castrated, with his testicles thrown into the fire below, because he was considered a heretic and suspected of 'unnatural' practices with the king (Johnes 1808: 32). Still conscious, Despenser was dragged from the gallows, a knife was plunged into his abdomen and his entrails and heart were cut out and burned. The corpse was lowered to the ground and decapitated. Figure 12 shows Froissart's depiction of Despenser's dramatic execution. On 4th December 1326 his head was displayed on London Bridge and the quarters of his body were sent to be displayed above the gates of Newcastle, York, Dover and Bristol (Cockayne 1919: 267-70; Viard \& Déprez 1904-5).

A few years later, Despenser's wife petitioned Westminster for his bones to be collected and buried on his family estate at Tewkesbury Abbey in Gloucestershire (Cockayne 1919: 270). Eleanor is said to have recovered her husband's head, a 'thigh bone' and a few vertebrae (N. Strawford, pers. comm. Tewkesbury Abbey Archivist), the very bones that are missing from HA16 (see Figure 2). The date of his death in 1326 fits with the ${ }^{14} \mathrm{C}$ dates (AD 1219-1385) and his age is more consistent with the osteological evidence than William Audley's. If the remains from Hulton Abbey are indeed those of Sir Hugh Despenser the Younger, then this is the first time such an execution victim has been identified. 


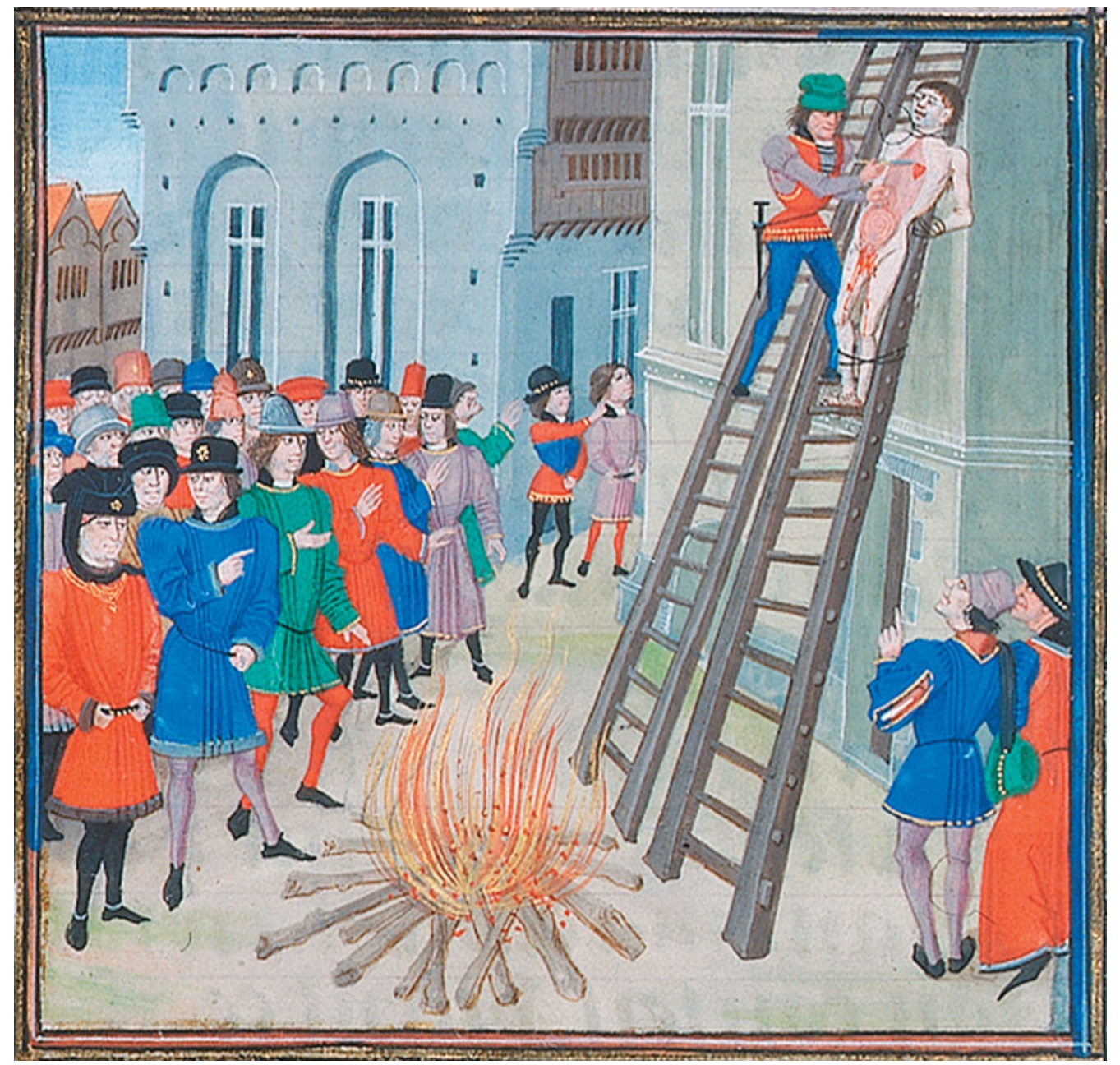

Figure 12. The disembowelment of Sir Hugh Despenser the Younger. Reproduced with kind permission of the Bibliothèque nationale de France.

\section{Disposal}

This case raises many interesting questions about how the remains came to be at Hulton Abbey. Although the pledge to distribute the quarters to four corners of the realm is well known, we do not know that this threat was actually carried out in this case, nor do we know if the 'quarters' included the torso as well as the limbs. If Hugh's remains were collected from their several display locations, then who did this? As a relative of the Audley's it may be expected that they would want to bury their disgraced relative in a quiet corner of their estate, and Hulton Abbey would not have been of great significance to them. But, given Despenser's attempts to have his brother-in-law executed, is it likely they would go to such an effort? Perhaps a monk from the monastery took it upon himself to gather the remains and bury them in the Abbey, so that all of his remains rested in consecrated ground. The 
Cistercians believed that during the resurrection, such scattered bones would be reunited to form one complete body (Bynum 1995: 121). As for the remains themselves, the removal of the hands is not a recorded part of the execution ritual. However, if this is Hugh then these may have been amputated with reference to his being known as a pirate and a 'thief'. Equally, the potential stab mark in the first lumbar vertebra is consistent with the stabbing in the abdomen recorded in the historical accounts, so perhaps are the cut marks to the surviving femur. It is possible that Despenser's 'drawing' may have been used as an opportunity for the angry spectators to strike him with their swords.

\section{Conclusion}

This paper has described the first known case of a skeleton displaying trauma associated with the practice of quartering in medieval England. In addition, it attempts to identify the remains and place them within their political and historical context. The distribution and nature of the lesions is not consistent with battle trauma or evisceration during 'division' of the body, but fits with the historical accounts surrounding the execution of Despenser. The date of the remains, from the founding of the Abbey (AD 1219) to the end of the 95 per cent confidence interval provided by the ${ }^{14} \mathrm{C}$ dates (AD 1385), fits with the period of his death and his age and sex is consistent with the osteological evidence. Probably most seductive in the identification of this body is the account of the remains buried at Tewkesbury Abbey, as these are precisely the skeletal elements missing from HA16.

However, such historical equations can never be completely proved. Despenser is said to have been buried at Tewkesbury and the matter must remain open unless and until the remains in the vault at Tewkesbury become available for analysis. Meanwhile we can say with more confidence that this was the skeleton of an execution victim, and the death of Hugh Despenser provides an analogy for the pathology observed.

\section{Acknowledgements}

I am grateful to Martin Carver and Malin Holst for their comments on the text and, in particular, James Bothwell for providing invaluable advice and references on the treatment of the medieval corpse.

\section{References}

BARRON, W. 1981. The penalties for treason in medieval life and literature. Journal of Medieval History 7: 187-202.

Bellamy, J. 1970. The Law of Treason in England in the Later Middle Ages. Cambridge: Cambridge University Press.

-1979. The Tudor Law of Treason: an introduction. London: Routledge \& Kegan Paul.

Brigstocke Sheppard, J. Rolls Series, 1889, iii: 404-12.

Brown, E. 1981. Death and the human body in the later middle ages: the legislation of Boniface VIII on the division of the corpse. Viator 12: 211-7.
BRowne, S. 2004. The human remains, in W. Klemperer \& N. Boothroyd (ed.) Excavations at Hulton Abbey, Staffordshire 1987-1994 (Society for Medieval Archaeology Monograph 21): 115-26. Leeds: Maney.

Bynum, C. 1995. The Resurrection of the Body in Western Christianity, 200-1336. New York: Columbia University Press.

Cockayne, G. 1919. Complete Peerage of England, Scotland, Ireland, Great Britain and the United Kingdom, Extant, Extinct or Dormant Vols I \& VI. London: St Catherine Press.

Cohen, E. 1989. Symbols of culpability and the universal language of justice: the ritual of public executions in later medieval Europe. History of European Ideas 11: 407-16. 


\section{A traitor's death}

FinuCANe, R. 1981. Sacred corpse, profane carrion: social ideals and death rituals in the later Middle Ages, in J. Whaley (ed.) Mirrors of Mortality. Studies in the Social History of Death: 40-60. London: Europa.

Fryde, N. 1979. The Tyranny and Fall of Edward II 1321-1326. Cambridge: Cambridge University Press.

Hedges, R., C. Housley, C. Bronk Ramsey \& G. Van Klinken. 1991. Radiocarbon dates from the Oxford AMS system. Archaeometry Datelist 13: 285-6.

Holmes, G. 1955. A protest against the Despensers, 1326. Speculum 30: 207-12.

Johnes, T. 1808. Froissart's Chronicles of England, France, Spain and the Adjoining Countries. London: printed for Longman, Hurst, Rees, Orme . . \& \& J. White.

Klemperer, W. \& N. Boothroyd (ed.). 2004. Excavations at Hulton Abbey, Staffordshire 1987-1994. Leeds: Maney.

Marfart, B., J.-P. Pelletier \& M. Fixot. 2004. Post-mortem ablation of the heart: a medieval funerary practice. A case observed at the cemetery of Ganagobie Priory in the French Department of Alpes de Haute-Provence. International Journal of Osteoarchaeology 14: 67-73.

Maxwell, H. 1913. Chronicle of Lanercost 1272-1336. Glasgow: J. Maclehose \& Sons.
PARK, K. 1995. The life of the corpse: division and dissection in late medieval Europe. Journal of the History of Medicine and Allied Sciences 50: 111-32.

Phillips, S. 2000. Simon de Montfort (1265), the Earl of Manchester (1644), and other stories: violence and politics in thirteenth and early fourteenth-century England, in R.W. Kaueper (ed.) Violence in Medieval Society: 79-90. Woodbridge: Boydell.

Pollock, F. \& F. Maitland. 1968. The History of English Law before the Time of Edward I. Cambridge: Cambridge University Press.

Royer, K. 2003. The body in parts: reading the execution ritual in late medieval England. Historical Reflections 29: 319-39.

Tomkinson, J. 1997. A History of Hulton Abbey. Stoke-on-Trent: City Museum and Art Gallery.

Valente, C. 1998. The deposition and abdication of Edward I. English Historical Review 113: 852-81.

Viard, J. \& E. Deprez (ed.). 1904-5. Chronique de Jean Le Bel. Paris: Société de l'Histoire de France.

Wise, P. 1985. Hulton Abbey: a century of excavations. Stoke-on-Trent: City Museum \& Art Gallery.

Wrottesley, G. 1887. Military services performed by Staffordshire tenants in the 13th and 14th centuries. Collections for the History of Staffordshire 8: 1-124. 